UDC 327.58(477):341.18«19»

DOI 10.24919/2519-058x.11.171314

\title{
Ihor SOLIAR
}

PhD hab. (History), Associate Professor, Director of the I. Krypiakevich Institute of the Ukrainian Studies, National Academy of Sciences of Ukraine, 4 Kozelnytska Street, Lviv, Ukraine,postal code 79007 (isoliar@ukr.net)

ORCID: https://orcid.org/0000-0003-0439-6957

\section{Khrystyna SHOLOTA}

PhD (History), Associate Professor of the Department of Foreign Languages, Faculty of International Relations, Ivan Franko Lviv National University, 19 Sichovych Striltsiv Street, Lviv, Ukraine, postal code 79000 (isoliar@ukr.net)

\section{Ігор СОЛЯР}

ORCID: https://orcid.org/0000-0001-6514-1988

доктор історичних наук, дочент, директор Інституту украӥнознавства ім. І. Крип'якевича Національної академї наук Украӥни, вул. Козельницька, 4, м. Львів, Україна, індекс79007 (isoliar@ukr.net)

\section{Христина ШОЛОТА}

кандидат історичних наук, дочент кафедри іноземних мов факультету міжнародних відносин Львівського начіонального університету імені Івана Франка, вул. Січових Стрільців, 19, м. Львів, Україна, індекс 79000 (isoliar@ukr.net)

Бібліографічний опис статті: Soliar, I. \& Sholota, K. (2019). Ukrainian issue at the National Minorities Congresses in the second half of the 1920-ies (based on the periodical «Dilo»). Skhidnoievropeiskyi Istorychnyi Visnyk [East European Historical Bulletin], 11, 142-168. doi: 10.24919/2519-058x.11.171314

\section{UKRAINIAN ISSUE AT THE NATIONAL MINORITIES CONGRESSES IN THE SECOND HALF OF THE 1920-IES (BASED ON THE PERIODICAL «DILO»)}

Summary. The purpose of the research - is to analyze the Ukrainian issue consideration on the basis of the publications in the newsapaper "Dilo», the interethnic relations in Europe in the format of the national minorities Congresses in the second half of the 1920--ies. The methodology of the research is based on the combination of historicism, the objectivity principles and a general scientific method, a special-historical method of the scientific work. The scientific novelty of the research is based on the fact that for the first time the Ukrainian representatives' composition at the National Minorities Congresses, the goals and the results have been researched; the content of discussions, the Ukrainian approaches to the solution of the national minorities problems in Europe in the second half of the 1920-ies have been also investigated. Conclusions. Consequently, the National Minorities Congresses, held annually in Geneva in the second half of the 1920-ies, became a discussion platform for negotiating a wide range of the national minorities problems in the inter-war Europe with the accedence of the League of Nations, which sent its representatives to participate in their discussions. The leaders of the Congress, J. Wilfan, E. Ammende and the others, tried to narrow the discussion of the problems of only those national minorities that were scattered in the European countries and enjoyed the support of their national powers. It was they who formed the agenda of Congresses, imposing debates on the implementation of the idea of the national 
and the cultural autonomy in various forms in European countries. But in Europe there were national minorities who, in separate countries (in their territories), lived compactly and in some regions constituted the majority without their national powers. The latter belonged to the Ukrainians whose representatives participated in the discussions of the above-mentioned issues. The Ukrainian position at the Congresses was represented by the UNDO representatives - the most influential Ukrainian political party in the 1920-ies (in different years, D. Levytskyi, M. Cherkavskyi, O. Levchanivskyi, D. Paliyiv, O. Maritschak, etc.) and the "Peasant Union» (P. Vasilchuk in 1926-1927), as well as Bukovyna and Transcarpathia representatives. In 1925 - 1927 the Ukrainian representatives were in the status of the observers, and in the subsequent years - the sufficient participants. The Ukrainian delegation at the Congresses advocated broadening the agenda Congresses, discussing the national minorities issue in the context of implementing the principle of the national self-determination, and considering the situation of certain national minorities in the individual states. The Ukrainian delegates did not consider the Ukrainians to be a national minority in Poland, and the format of the Congress was viewed as an opportunity for the Ukrainian issue propaganda on the international scene. The allies of the Ukrainians were often the representatives of the Belarusians, the Lithuanians, and the others.

Key words: Ukrainian issue, National Minorities Congresses, Ukrainian National Democratic Organization (UNDO), national cultural autonomy.

\section{УКРАЇНСЬКЕ ПИТАННЯ НА КОНГРЕСАХ НАЦІОНАЛЬНИХ МЕНШИН У ДРУГІЙ ПОЛОВИНІ 1920-Х РОКІВ (ЗА МАТЕРІАЛАМИ ЧАСОПИСУ «ДІЛО»)}

Анотація. Мета статті - проаналізовано розгляд украӥнського питання, міжнаціональних взаємин в Свропі у форматі Конгресів національних меншин у другій половині 1920-х рр. Методологія дослідження спирається на традиційне для історіографічних праџь поєднання принципів (історизму й об'єктивності) і методів (загальнонаукових та спеиіально-історичних) наукової праці. Наукова новизна полягає у тому, щзо вперше досліджено склад, иілі та результати діяльності украйнського представництва на Конгресах національних мениин, зміст дискусій на них, українські підходи до розв 'язання проблем національних меншин у Європі в другій половині 1920-х рр. Висновки. Конгреси начіональних меншин, які відбувалися щзороку в другій половині 1920- х рр. у Женеві, стали дискусійним майданчиком для обговорення широкого спектру проблем національних меншин у міжвоєнній Європі з відома Ліги Наиій, котра направляла свого представника для участі в їх обговоренні. Лідери Конгресу Й. Вільфан, Е. Амменде та ін. намагалися привернути увагу до тих нащіональних меншин, які були розсіяні в європейських державах і користувалися підтримкою своїх національних держав. Саме вони формували порядок денний Конгресів, нав'язуючи обговорення реалізаиії ідеї національно-культурної автономії в різних формах у європейських державах. Але в Свропі були національні меншини, які в окремих країнах (на їхніх територіях) проживали компактно і в окремих регіонах становили більшість, не маючи національних держав. До останніх належали українці, представники яких долучилися до обговорення вищеназваних питань. Українську позиџію на Конгресах озвучували представники УНДО - найвпливовішої у 1920-х рр. української політичної партії (у різні роки Д. Левицький, М. Черкавський, О. Левчанівська, Д. Паліїв, О. Марітчак та ін.) $i$ «Селянського Союзу» (П. Васильчук у $1926-1927$ рр.), а також - Буковини і Закарпаття. Украйнські представники у 1925 - 1927 рр. мали статус спостерігачів, а в наступні роки - повночінних учасників. Украӥнська делегаџія на Конгресах виступала за розширення тематики порядку денного Конгресів, обговорення проблеми національних меншин у контексті реалізаиії принципу національного самовизначення, аналізу становища окремих національних меншин в окремих державах. Українські делегати не вважали українців у Польщі національною меншиною, а формат Конгресу розглядали як можливість пропаганди на міжнародній арені украӥнського питання. Союзниками украӥнців часто виступали представники білорусів, литовиів та ін.

Ключові слова: украӥнське питання, Конгреси національних меншин, УНДО, національно-культурна автономія.

Problem statement. The Treaty of Versailles (the system of international treaties) failed at solving all the national minorities problems in Europe after World War I, as well as the League of Nations created by it. In particular, in the interwar period of the XXth 
century the Ukrainian issue remained unresolved. The Ukrainian statehood wasn't even on the European international relations agenda. There wasn't any European state, which defended the Ukrainian people's right to create an independent and constituent state. For obvious reasons, this problem was not discussed in the USSR. The Naddnieprianski parties, after the defeat of the Ukrainian Revolution in 1917 - 1921, were trying to draw attention of the European leaders in order to solve the Ukrainian statehood problem in the emigration, but their efforts were unsuccessful. The Western Ukraine, which belonged to Rzeczpospolita II (the Second Polish Republic) in 1923 - 1939, having political struggle historical traditions under the conditions of the Austro-Hungarian Empire, the experience of state-building during the Ukrainian Revolution in 1917 - 1921, the greatest influences (among the legal parties) on the Ukrainian social-political life of the region, the nationalstate parties (Ukrainian National-Democratic Union (UNDO), Ukrainian radical party (since 1926 - Ukrainian Socialist-Radical Party (URP-UDRP), Ukrainian Social Democratic Party (USPP) attempted to actualize the Ukrainian issue in the international arena, however, only the National Democrats (UNDO) were most actively trying to use the format of existing international organizations (The League of Nations, The League of Nations Societies, The National Minorities Congresses, The Inter-Parliamentary Union, etc.).

The analysis of the sources and recent researches. This problem is not completely researched in Ukrainian and foreign historiography. In the interwar Rzeczpospolita II the national minorities problems were interested in a number of scientific institutions, including the Institute for National Studies and the Eastern Institute. On the pages of their printed periodicals - «Sprawy Narodowościowe», «Wschód», «Biuletyń Polsko-Ukraiński» there were often analyzed the international relations in Central and Eastern Europe, the international relations in Poland and some aspects of the Ukrainian foreign policy. In the Ukrainian historiography of this period the works of P. Klunnyi (Klunnyi 1924), K. Levytskyi (Levytskyi, 1923), M. Lozynskyi (Lozynskyi, 1923), M. Mandryka (Mandryka, 1926) are distinguished. The works of the above-mentioned authors characterize, in the popular scientific form, the issue of protecting the national minorities in international law after the end of the World War I, especially in the Versailles Treaty system. One of the leaders of the National Minorities Congress, a German public figure, a scientist, E. Ammende analyzed the situation of the German minority in European countries (Ammende, 1927).

In modern Polish historiography, the problem of the national minorities in Rzeczpospolita II, in the interwar Europe of the XXth century in general, much more scientific works are devoted than in Ukrainian historiography. In the researches of M. Batóg (Batóg, 2017), S. Bober (Bober, 2018), V. Kundera (Kundera, 2016), the general approaches of the national policy of the Polish governments of the interwar twenty years are analyzed. The situation of the Ukrainians in the interwar Poland, their national rights and freedoms became the subject of the study of A. Dawidowicz (Dawidowicz, 2016), M. Figura (Figura, 2016), M. Koziński (Koziński, 2016), M. Marszał (Marszał, 2014), Yu. Pisuliński (Pisuliński, 2017) and the others. The UNDO policy on solving the Ukrainian issue in the international arena was partially analyzed by R. Torzecki (Torzecki, 1989), R. Tomczyk (Tomczyk, 2006), and the others. In Ukrainian historiography, certain aspects of the above-mentioned problem were considered incidentally by I. Vasiuta (Vasiuta, 2006), O. Zaitsev (Zaitsev, 1993, 1994), M. Kuhutiak (Kuhutiak, 2000, 2002), and the others.

The source basis of the article is the materials of the daily newspaper «Dilo», devoted to the problem of solving of the Ukrainian issue at the Congresses of the national minorities 
of the second half of the 1920-ies, as well as the documents of the Central State Historical Archives of Ukraine in Lviv, the Central State Archive of Public Associations of Ukraine, the published researches (Rudnytska, 1998).

The publication's purpose is the analysis of the consideration of the Ukrainian issue and the interethnic relations in Europe in the format of the national minorities Congresses in the second half of the 1920-ies. To achieve the goal the authors set the task to investigate the composition, the purpose and the results of the Ukrainian representatives' activity at the national minorities Congresses, the content of the discussions, the Ukrainian approaches to solving the national minorities problems in the second half of the 1920-ies.

Statement of the basic material. The idea of summoning of the National Minorities Congress arose in the mid-1920-ies. Already on October 14, 1925, the Slovenians, who lived in Italy, the Germans from Latvia and the Hungarians, who lived in Czechoslovakia, summoned the international meeting in Geneva, whose main task was to prepare the Congress of the enslaved nations. The previous Geneva meetings of European national minorities representatives were limited to the consideration of the cultural autonomy and free economic development issues. The editorial of the newspaper «Dilo» expressed some surprise at the fact that there was no mention of the self-determination of the peoples, while at the meetings only the questions «the position of individual national groups in European state» were considered (Konhresy ponevolenykh, 1925).

The agenda of the meeting on October 14, 1925 was limited to four items: 1. The greetings of the invitees; 2 . A national tolerance as a principle of an international law; 3 . The value of a self-governing principle for the achievement of the national peace; 4 . The task of international organizations, in particular, the League of Nations.

On the basis of the prepared resolutions the thesis was emphasized: «the national, cultural freedom as well as the religious freedom must find its true expression in the positive legal norms. Each state, at whose borders live other national groups, must provide them with free cultural and economic development and the opportunity to use civil rights (civil - the authors) along with the state nation. Each national group must have the right to create and develop community-based institutions, depending on the circumstances - on a territorial or personal basis. The defense of these rights is the responsibility of the League of Nations and all organizations that have set themselves the task of maintaining world peace and cohabitable living among the peoples» (Konhresy ponevolenykh, 1925).

The representatives of the Ukrainians and the Belarusians did not agree to this platform. «The basis and directions of this first preparatory meeting of European national minorities cannot satisfy the subordinate to the ruling peoples of the territorial peoples or their larger branches ... Those who summon the meeting are the representatives of the skillful national groups and then, of course, the non-territorial ones. So, it is no wonder that their demands are directed to the national, cultural autonomy. In addition, the initiators of this first meeting of European national minorities would like to spread the right legally and loyally, but rather implement the rights based on the Alliance Theses (Entente States - auth.) on the protection of the national minorities» (Konhresy ponevolenykh, 1925).

The initiators of the meeting did not distinguish the territorial and non-territorial peoples, large and small national groups, but only tried to create the basis for the minimum cultural rights of the non-state peoples. Despite the difference in Ukrainian demands with the resolutions of the meeting, the Ukrainians did not refuse to participate in the preparatory meetings of the Congress of enslaved peoples. The representatives of the Ukrainians set themselves the 
goal «to extend the scope of the Congress also to the matters of a wider political significance, which would include the requirements and natural rights of the territorial peoples» (Konhresy ponevolenykh, 1925).

The representatives of the Ukrainians in Poland believed that Geneva meeting would give an impact to the creation of a uniform front of the national minorities and non-state peoples. The Head of the Ukrainian Parliamentary Representation (UPR), a member of the Central Committee of the Ukrainian National-Democratic Union (Central Committee of the UNDO), M. Cherkavskyi, stated that the Ukrainians received the information about summoning the Congress with a great interest. "Though from the top, - said the national democrat, - the fixed «frames» of the Congress are very narrow, the Congress has the right to change its program according to the wishes of the majority. But even when the Congress limited to the cultural issues, then its value would be great» (Konhresy ponevolenykh, 1925).

M. Cherkavskyi, O. Levchanivskyi, P. Vasilchuk went to the Congress (On October, 14 1925 in the newspaper «Dilo» there was published the information on the first two persons) The issues of Geneva Conference became the subject of the international meetings not for the first time, because the above-mentioned issues were considered for the numerous times at the meetings of the League of Nations Societies Union. The newspaper «Dilo» put an emphasis on the following point: «The only difference is that this time in Geneva, the initiative of such Congress came from the offended national minorities, who did not want to be controlled by the «senior guardians» performing the role of the peace judges. It was hard to predict the limits of the extension of the Congress programme, because it depended on the position of the participants. «The pursuit of the national, cultural autonomy is the maximum programme for some people, who are the disappearing minority in the state, for the others - the minimum programme. There are as many forms of the autonomies as the state systems and state regimes» (Zhenevska konferentsiia, 1925) While clarifying the situation, regarding the observance of minimum obligations for the national minorities protection by the European States, their discussion at the VIth session of the League of Nations, the editorial staff of the newspaper «Dilo» emphasized: «The basic fact that each of the states, having committed itself against the national minorities, performs them on their own means, that is, they are seeking for the other means to carry them out at least - this fact has given the impact to the Lithuanian delegate at the last meeting of the League of Nations to make some additions, so that the minorities rights protection will have one form in all states. The discussion in the political commission of the VIth session of the League of Nations was the best evidence that attempted to extend the same forms of «freedoms» to the national minorities to all states may still can wait for a long for their implementation. There is a little evidence that the International Human Rights Protection Commission agreed on a new procedure, considering that this is not in the interest of the great powers» (Zhenevska konferentsiia, 1925).

The Ukrainians were afraid of the similar situations that happened at the meetings of the League of Nations Societies Union when the Italians, the Slovenians, the Baltic Germans and the Czechoslovak-Hungarians would invite the national minorities representatives, who have formed their own states, and had their own national minorities: «Poland, for example, is ready to seek for the one-percent national minority autonomy in Ukraine, considering the fact that such kind of autonomy for 22 percent of the Ukrainians in its state is completely different, because these Ukrainians don't come from Ukraine (there are only MaloRussy and Rusyns), or they are at such a low cultural level that any autonomy would be harmful to them» (Zhenevska konferentsiia, 1925). 
The Ukrainians considered the Geneva Conference's first task to find the ways to put pressure on the international community in order to improve the oppressed peoples. «Small national minorities, according to «Dilo», who organize the conference, do not see that securing their claims is possible only when a few million national minorities are on their side, even more offended by the small branches of those minorities» (Zhenevska konferentsiia, 1925).

On October 14, in 1925, the European National Minorities Congress began to work. At the organizational meeting, it was argued that 30 groups that declared their desire to participate in it, identified the official delegates or the political leaders. The Slovenian Ambassador to the Italian Parliament, Dr. O. Wilfan, was the head at the meeting. The discussion on the internal situation of the individual minorities, their peculiar situation, the protests have been excluded from the Congress agenda programme in advance.

Having agreed on the Congress agenda, a closer committee of 12 people was elected to organize the Congress. It included the Ukrainians along with the Hungarians, the Dutch, the Belarusians, the Poles, the Jews, and the Germans. At the end of this opening meeting, the Ukrainians and the Belarusians made an offer to consider the issue of peoples' selfdetermination, which was immediately sent to the Twelve Congress Committee, which rejected this proposal. Then the Ukrainians and the Belarusians representatives declared the statement in which they emphasized: «We, are the Ukrainian and Belarusian population representatives annexed to Poland against our will, assert that our two nations, who inhabit their own national territory, one third of the entire Polish state, are creating the prevailing national majority which we have sought for the full realization of the self-determination rights provided by their international laws». The above-mentioned petition was signed by F. Yeremich, O. Levchanivskyi, M. Cherkavskyi and P. Vasylchuk. (Konhres yevropeiskykh natsionalnykh menshostei, 1925).

The subject matter of these Congress meetings were the minimum requirements of the «groups national protection, exclusively based on the national and the cultural grounds, the claims for our national units are not enough, and the Congress is reluctant to extend the subject of the meetings to the limits of the national self-determination, nor to allow the situation of the individual national groups, we declare that our active participation in this Congress will become possible only when such kind of a Congress will only deal with the national minorities protection who are scattered in the foreign territories, but that the questions of the full realization of the self-determination rights and the individual position of the individual national groups» (Konhres yevropeiskykh natsionalnykh menshostei, 1925). Before the implementation of these requirements, the Ukrainians and the Belarusians participated in the Congress in the status of the observers. A similar statement was made by a representative of the Lithuanians.

As a result of the work of the Congress, the resolutions were adopted on October 15, 1925, which emphasized: «A national, cultural freedom is just the good of a cultural world as a religious one. This axiom must be recognized by everyone as an ethical principle for the national relations, and it must find its expression in the positive state laws and means of a public life. According to it, each state, within which other national groups also live, must provide these citizens with the right to a free, economic development, and to its members a full use of all civil rights. The aim and practical implementation of those principles create the precondition for understanding between the peoples, and thus the precondition for peace in Europe» (Konhres yevropeiskykh natsionalnykh menshostei, 1925).

At the same time, the Congress participants confirmed the need for the rights of these national groups to cultivate their national culture, to create political organizations, to 
implement the principles of self-government. The resolution was sent to the League of Nations by the Congress. The Congress also expressed its sincere gratitude to all international organizations involved in solving the problem of the national minorities and asked them to «continue their work in accordance with their grand purpose» (Konhres yevropeiskykh natsionalnykh menshostei, 1925).

Summing up the results of the work of the Congress, the editorial staff of «Dilo», expressing the position of UNDO, noted: " It is wise to avoid irritating issues at the international congresses in order to maintain a harmonious atmosphere. But it is not entirely wise to reject the investigation of the real circumstances in which the peoples live, when the purpose of these resolutions is the correction of these circumstances» (Konhres yevropeiskykh natsionalnykh menshostei, 1925).

In the interview of «Dilo», the member of the Ukrainian delegation, M. Cherkavskyi, described the circumstances of the announcement of the Ukrainian delegation: «At the opening of the conference, it was agreed that each representation must give one of its members to the presidium of the vice president. Therefore, in the Presidium there was a place for us, and for the Belorussians. When after the opening of the conference there came to the turn the election issue of the presidium, and when the President Wilfan appealed to the attendees with the request, if anyone had any intention of making the declaration, then we made our declaration in the following order: the predeclaration speech was made in Belorusian by the Ambassador Yeremich, stating, that his speech must be translated into German by a Senator Levchanivska. The senator, having retold the content of Yeremich's speech, made clear the motives, due to which we can neither be satisfied with the meetings programmes, nor take part, because we are the national majority in our territories, which are occupied by Poland, because there are above 6 million of people of our population, because the very international law guaranteed even more than territorial autonomy. Senator Levchanivska finished her speech by reading the declaration, which was given in a written form to the presidium» (Do zizdu ponevolenykh v Zhenevi, 1925).

Answering the question about the concrete consequences of this congress, M. Cherkavskyi stated: «Now it's hard to predict, because this congress was the first congress of national minorities. It is called the so-called. executive committee. Despite our declaration and the fact that we were at the Congress as the observers only, in the executive office there were two places reserved for us and for the Belarusians» (Do zizdu ponevolenykh v Zhenevi, 1925).

The Second National Minorities Congress began in Geneva on August 25, in 1926, with the participation of the representatives of 39 national groups: 10 Germans, 5 Jewish, 5 Polish, 3 Ukrainians, in particular one representative from Pidkarpatska Ukraine, 3 Russians, 3 Hungarians, 3 Slovenians, 1 Belarusian, 1 Lithuanian, 1 Czechoslovak, 1 LusutskoSerbian, 1 Danish and 1 Swedish. Most of the national groups came from Poland (there were 6 national Polish groups), Czechoslovakia - 5, from Romania - 4, from Germany - 3, from Austria - 2, from Italy - 2, from Yugoslavia - 2, there were 1 national group from Denmark, 1 from Spain, 1 from Hungary. The secretary of the congress worked at the Victoria Hotel, led by Dr. E. Ammende (Konhres natsionalnykh menshostei, 1926 a).

On August 22, in 1926, the Ukrainian delegation headed by UNDO D. Levytskyi, Deputy Head of the UNDO M. Cherkavskyi, O. Maritschak left for an Organized National Groups Congress. According to the newspaper «Dilo», the Ukrainian delegation said in advance that it would not take an active part in the Congress because of the fundamental positions, it would confine itself to issuing a statement of the principle, it would work as observers, it would try to contact the enslaved peoples' representatives and the national minorities (Novynky, 1926). 
The Polish minorities consisting of five countries formed a common front under the leadership of delegates from Germany. The Jewish minorities delegates elected Dr. L. Motskin as their joint delegate equally. The German delegates from different countries did not find an agreement, since the situation of the Germans in the different states was significantly different. In particular, the Germans in Romania demanded the creation of a special League of Nations in order to protect the national minorities interests.

At the National Minorities Congress four commissions were elected: economic, cultural, organizational and legal political. The representatives of the League of Nations in Geneva maintained a neutral position before the Congress (Konhres natsionalnykh menshostei, 1926 a).

The Ukrainian delegation proposed to include into the agenda the change of the borders of the existing states and the enslaved peoples' independence. This proposal was supported by the Belarusians, but it was not supported by the Congress. Similarly, there was no proposal to create a separate League of National Minorities. The Congress discussed only the cultural and the economic problems of the national minorities.

The newspaper «Dilo» evaluated the Congress programme without much optimism (Konhres natsionalnykh menshostei, 1926 b). There was no great interest in this Congress not only from the European leading powers, but also from their official representatives. The leadership of the League of Nations sent to the Congress a referent of «complaints» of the national minorities. The world press reacted to topics, which were violated by the Congress, mainly in the referring tone.

More than 100 delegates came to the Congress, representing 17 organized national groups. The opening ceremony took place on August 25, in 1926 at Victoria Hotel, with an opening speech announced by the chairman of the Congress, O. Wilfan. He stressed out that only organized national groups were allowed to take part in the Congress, which found independent cultural competitions - from Czechoslovakia, Romania, Yugoslaviya, Spain, Germany, Poland, and the others. The main task of the Congress is to ensure the freedom of the national and the cultural development of minorities. The agenda also included the following discussions: the linguistic issue, the economic equality, the ensuring citizens' rights, the electoral equality, and resolving the conflict between the national minorities and the state. The observers noted the differences between the national groups in solving these issues, but they were united by the desire to resist the restriction (or the destruction) of the national-cultural rights (Konhres natsionalnykh menshostei, 1926 b).

M. Anghazel, the Catalans representative, said that the Catalan group, through its participation in the Congress, did not renounce the rights «arising from the full harmonization of the national principle» (Konhres menshostei, 1926). On the contrary, his participation in the Catalan Congress expressed hope for a peaceful solution to the national question. On behalf of the Russian group, the Congress welcomed the ambassador to the Estonian parliament, Kurchinskyi. The head of the Congress reported that the Ukrainians, the Belarusians, and the Polish-Lithuanians took part in the Congress only in the status of observers, «because their nations, interceded by them, defend the principle of the very definition of nations» (Konhres menshostei, 1926).

The Hungarian delegate from Czechoslovakia, Sillie said that the minorities issue is an illness of the whole Europe, and the Congress task is to find «remedies» to cure that illness. According to him, «The League of Nations did not find such a medicine. She wants to save her current condition. Minorities must fight and appeal to the world, namely, to the United States» (Konhres menshostei, 1926). In general, in his conviction, «a minority issue can be 
solved only in the sense of love and justice, «because for how long the minority is not equal, how long they are only legal residents but not the citizens, how long in the world there are armed and unarmed states, how long in the world does not prevail the commandment: love your neighbor as yourself - so long the world will be sick» (Konhres menshostei, 1926).

On the behalf of five Jewish groups (from Poland, Lithuania, Latvia, Czechoslovakia, Romania) L. Motskin spoke in favor of elaborating a moral code of relations between nations. «Nationalism only then will be true», he stressed, «when it will be understood for the other nationalities» (Konhres menshostei, 1926). The great interest among the participants of the Congress was the statement of the head of the German faction in the Estonian parliament P. Schiman, devoted to the attitude of the national minorities to the state. He called for the creation of a new law that could equalize the differences between the national and the state affiliation: «minority interests require the legal protection against the state. This is a prerequisite for the preservation of the world. The right to nationality must be given a stick, a competitive form. The League of Nations can regulate only relations between the states, but it cannot mean the relationship between the state and the citizens or groups of citizens entering into its structure. The principle of self-determination affects a state-owned entity that is not identical to a national affiliation. The right for self-determination does not make equal that opposition and is not a means to create a peaceful coexistence of different nationalities in the same territory. The treaties on the national minorities protection make these minorities a subject to bidding between the states. Inside the states must be created a new state law, a positive right of the people» (Konhres menshostei, 1926). He once again expressed the thesis about the creation in the state of freedom for the nurturing of national culture, the separation of the cultural sphere from the custody of the state» (Konhres menshostei, 1926).

A Jewish ambassador to the Lithuanian Parliament, Robinson continuing the theme of cultural autonomy, he proposed the relevant resolutions: «1) the national and cultural autonomy comprehension should be dependent only on the will of the minority; 2) the recognition of a given national minority must be dependent on the will of the unit and dare not to cause any harm to it; 3 ) the State duty is to allocate from its budget subventions for the cultural minority purposes in proportion to the size of the minority» (Konhres menshostei, 1926). However, these proposals were not supported by I. Greenbaum, a representative of the Polish Jews, who expressed their support for the territorial autonomy claim for the territorial minorities. As a result of the discussion, the resolutions proposed by Robinson were adopted.

In the linguistic case, the Congress passed a resolution on the state language as compulsory only in the administration. Concerning the resolution of conflicts between the governments and the national groups, it is proposed to form parity commissions for their solution.

An important outcome of the work of the Ukrainian delegation was the mutual understanding between the Belarusians and the Lithuanians, who took a common platform on the activities of the Congress. D. Levytskyi, O. Maritschak, M. Cherkavskyi, F. Yeremich, V. Zalmeskavs on behalf of their delegations expressed it in a joint statement: "As it is known, our representatives at the first conference of nationalities in Geneva last year made a statement that they could not take an active part in the Congress work, but for the reasons given in that statement, they are competing for the full realization of the self-determination right. For this reason, our representatives made an application for the conference foundations in the above-mentioned direction. The Conference Council did not accept our introduction. The basics of this year's Congress are stagnant in the same narrow framework as last year. Given that the right to complete the very definition of nations is definitely the ultimate basis 
for their political development and for the peaceful coexistence of peoples, we cannot take part in the Congress works this year» (O. N., 1926).

The Congress work lasted for three days and touched the political, the economic and the cultural enslaved peoples. On the basis of the lectures and discussions O. Maritchak shared his observations: «The referents and the conversations were passing through the Congress program and were able to make sure that the resolution of the problems of the enslaved peoples - even the actual national minorities - would not allow the settled platform of the Congress» (O. N., 1926).

Outside of the UNDO, none of the other Ukrainian political parties tried to use this Congress. Only the representative of the Peasant Union - P. Vasilchuk, in a separate letter to the secretary of the Congress, M. Ammende refused to attend the Congress, stating reasons that made his presence unnecessary. In the periodical «Nashe Zhyttya (Our Life)», he stated frankly: «When the enslaved are taken up, they have the right to represent themselves and the opinion of the world in their actual situation. What's the reason for summoning the Congresses when you cannot tell the truth about your mode of life? What for repeating the well-known theoretical formulas, while being limited, - or only from the ad to show up ... A union of the enslaved, who would say to the world about his right to life loudly, is needed. The Geneva Congress of «European National Groups» is the Congress of National Agreed groups, gives way to the existing regime, which appeared after the war, it is not a union of enslaved territorial peoples, who would widely and fundamentally take the national question in the enslaved states» (Pislia konhresu menshostei, 1926). The Krakow periodical «Time» did not believe in certain positivity for Poland, because our policy «in relation to the minorities is non-conservative and unwise. The creators of the constitution introduced a lot of unpredictable and impractical resolutions, promising the minorities too broad «selfgovernment», which in the end the minority does not have and do not need anywhere» (Pislia konhresu menshostei, 1926). T. Goluvko at the periodical «Robotnik», on the contrary, praised the united Polish delegation behavior, as well as the European representatives

While analyzing the results of the Congress in the articles of the newspaper «Dilo» «The Oppressors Union», «the Union of the Oppressed» it was «clearly indicated that the Congress of the organized national groups in European states» «cannot have any real consequences: «Narrowing the scope and the content of the Congress to small and purely abstract themes, preventing criticism of the existing regimes in some states - all these looked like the unnecessary meetings but not the courageous and serious approach to the national problem» (Pislia konhresu, 1926).

For those politicians of the national, democratic group in 1926, it became clear that the Congress had neither «demonstrative nor practical significance» (Pislia konhresu, 1926). Moreover, they then had the impression of the initiative of conducting the Congress by the»insurgent states in order to bury the most important right of our century, the right for self-determination of the peoples by the organized national groups» (Pislia konhresu, 1926). According to the newspaper «Dilo», two consensus blocks met at the Congress: «German minorities and Polish; to these last joined and the Polish Russians with the ambassador Serebrenikov and Halytski katsapy (Moskvophiles - the authors)» (Pislia konhresu, 1926). They tried to remove the principle of the right for self-determination beyond the Congress. The Ukrainian politicians even questioned the moral value of this organization.

The Third Congress of the National Minorities took place on August 22 - 24, in 1927 in Geneva. On August 1, in 1927, the Ukrainian, the Belarusian and the Lithuanian groups in 
Poland held a joint meeting and on August 3, during the same year the letter was sent to the Congress presidium with the terms of the cooperation at the IV Congress. The conditions were based on the declarations of 1925 and 1926: «1) the assumption of the statement that the participation in the Congress of these groups does not mean the abdication of the national-political competitions of the Ukrainian, the Belarusian and the Lithuanian nations and their self-determination right; 2) the extension of the Congress discussion framework, which allows only the theoretical considerations on the minorities protection, to eliminate the frustration and the unlawfulness of the enslaved peoples in the European individual states; 3 ) the national minorities loyalty requirement removal against the ruling powers, which was indicated at the first and second Congress discussions; 4) the admission of two representatives of the above-mentioned groups to the presidium of the Congress» (Maritchak, 1927).

On August 21, in 1927 the Congress presidium was dealing with the above-mentioned conditions. In addition, the Frisians adoption issue from Germany was discussed, which found the protectors among the Polish delegation from Germany. The Congress Presidium was prone to meet the requirements of the representatives of the Ukrainians, the Belarusians and the Lithuanians from Poland, but the Congress Council, which consisted of one representative from each nationality, was unable to resolve the issue of accepting the new members and decided to prepare the first statute, on the basis of which it would be possible to take new groups The Ukrainian and the Belarusian delegations were invited to participate in the Congress in the status of the observers.

While analyzing the course of the Congress, the researcher O. Maritchak put an emphasis on the following: «The practical instructions for solving the important problem of the enslaved peoples in the abstracts are not presented and this circumstance encouraged numerous delegates to the congress. In the individual states Parliaments, the enslaved peoples representatives have far more freedom in discussing the affairs of the nation, as in the Congress itself, the enslaved ones. This was an anomaly, which was felt by the delegates who weren't able to attend the Congress, and which some observers also raised» (Maritchak, 1927). The author saw the task of the Congress in finding a common practical way and the common language of all enslaved peoples.

Putting aside the affairs connected with the friezes adopted to Congress, the Polish delegation protest and the congressional meetings resignation, the withdrawal from the organization of the Germans of Czechoslovakia, have greatly increased the tension in the Third Congress. O. Maritchak advised the Congress secretariat «to take seriously the events that took place at the last Congress and with a greater understanding to lead the further work of the enslaved organization» (Maritchak, 1927).

The Third Congress of National Minorities in Geneva ended with the Poles and the Dutch withdrawal from the organization. The reason for this decisive step, according to the official communique of the secessionists, was the Germans' opposition to the adoption of the Frisians and the Vends (Latvian vendi) - two thousandths of minorities in Germany. According to the newspaper «Dilo», «the initiators and founders of this institution were the Germans, and then the Baltic Germans, it means: the most loyal element. They gathered the scattered minorities and bound them in one whole on the platform of the Treaty of Versailles and its branches. The invincible holiness for them was the existing borders imposed by the winners in the World War. Preserving the modern states boundaries, they advanced only the development of the minor treatise, but not on the basis of the reality, the living life, its needs and postulates, but based on the transcendental dissected theses and formulas. As the situation came to a 
standstill, the national minorities unification thus became the right hand, the donor of the official League of Nations, whose task was to crush the national problem» (Menshostevyi olimp, 1927). With such a platform, the UNDO representatives could not find the agreement.

At the Third Congress it was proposed to consider the following abstracts: 1) about the European peace threat as a source of the national tolerance; 2) on the domestic and interstate cooperation of the nationalities; 3) about the problem of the languages; 4) on the state sovereignty and the minorities rights; 5) about the organization and the propaganda. The delegation, consisting of D. Levytskyi, M. Cherkavskyi, O. Maritchak, left for the Congress (R. Yasenytskyш joined the Ukrainian delegation from Bukovina) (Konhres ponevolenykh narodiv v Zhenevi, 1927).

The Ukrainian politicians did not agree with the status of the Ukrainians as the national minority. They believed that the actual national minorities: the German, the Hungarian, the Polish and the others were in a much better position than the Western Ukrainians. The UNDO representatives understood that it was not enough to use the Geneva National Minorities Congresses to declare their principle status, while remaining passive. After the Third Congress it was written in the newspaper «Dilo»: «The task of our representation is to find such a formula, which, on the one hand, would enable it to live on the international scene and, on the other, would not weaken our principledness» (Konhres ponevolenykh narodiv v Zhenevi, 1927).

The Fourth Congress of National Minorities began its work on August 29, in 1928 in Geneva. The researcher O. Maritchak noted that «in the order of the meetings, we see many theoretical issues that don't have any practical importance for preparing the solution to the complicated issue of the enslaved nationalities» (Maritchak, 1928). In particular, in 1928, it was planned to consider the following issues: 1) the status of the nationalities and the League of Nations; 2) the cultural work of nationalities and their cultural attitude towards the indigenous peoples; 3 ) the activities of the international organizations on the nationalities issue and the nationalities cooperation within their framework; 4) the question of the nationality science: a) the nationalities struggle and the set forth by law; b) the continuation and the development of the biography; c) the European nationalities statistical textbook preparation issuance; d) the finality and the structure the Intereuropean Institute for the Nationality Science « (Maritchak, 1928). The researcher believed that the main reasons for the past Congresses disorganization were the following: 1) its narrow political platform, the uncertain position of the Germans of Czechoslovakia. In particular, the Third Congress «stuck in small formal affairs, which almost did not lead to the organization's breakdown. The main offensive against the organization was led and conducted by the Poles, who used the false foundations of the organization for their calculations with Germany's domestic policy against the national Minorities» (Maritchak, 1928).

O. Maritchak insisted that «while solving the complicated issue of the enslaved nationalities, the idea of single peoples movement should be taken, one big, indomitable idea. With dry material, even the most intelligent essays cannot solve this question as it cannot be resolved from a loyalty position against the ruling ones. Without an idea, there can be no extension in any action, and even more so in the action that forms the ground for making peace in Europe - and the lack of ideas caused by the infirmity of all the enslaved nationalities Congresses, which the organizers did not have the courage to face and resolve to fight for the idea, which alone could unite all theenslaved nationalities into one front. The idea is great, it was born out of the blood of millions of victims of the World War, and its name: a true, a complete self-determination of the peoples» (Maritchak, 1928). 
An interview with the Belarusian Ambassador F. Yeremich, and the UNDO and the UPR Chairman, D. Levytskyi, was published in Lviv Jewish Diary «Der Morgen» on September 4, in 1928, on their participation in the National Minorities Congress. The Belarusian representative stressed out the following: «Life will force the Congress to take a new position, and only the conviction that this will happen, could cause my participation as a Belarusian representative in that Congress. However, I ask you to emphasize strongly in the press that our participation in the Congress is not ambiguous with the plague of a further struggle for the full rights of our nation» (Interviu, 1928).

D. Levitskyi, answering the question: «What happened that you have finally decided to come to the National Minorities Congress officially», stressed the position of the Ukrainian delegation: «Nothing happened. Through our introduction, we wanted to show that, being a national majority in a densely populated area of our country, we must still fight for the most primitive minorities rights that are guarded by the Congress. In the previous years, we have rescued our congressional membership due to the loyalty clause. In my opinion, no national minority, which is threatened in its national existence, cannot be loyal to the state and the government under which it was necessary for it to live. The edges of the Congress are rather narrow and they are tied up to the conditions in which the national minorities live, for example, the Jews. The political tendencies of Ukrainians, who in their national territory are not a minority, but a majority, are going in a completely different direction as the direction of those goals that the National Minorities Congress considers. I have quite clearly stated in our declaration, and only because we, the Ukrainians, do not even have the rights for which the National Minorities Congress is fighting - we participate in it. I want to document that we are forced to fight hard even for the rights guaranteed to us by the international treaties» (Interviu, 1928).

On August 26, in 1929, the Vth Congress of National Minorities took place with the participation of the representatives of 15 peoples. The head of the UNDO D. Levytskyi and D. Paliyiv came from Poland as the Ukrainian representatives, from the Russians-Serebrenikov and Yurchakevych, from the Non-Party Block of Cooperation with the Government Roskosh and Bohuslavskyi, from the Jews - Greenbaum and Reich, the Lithuanian - Tachik. The Belarusian did not participate in the Congress. The Polish minorities and the German Minorities Union did not participate either because the Congressional Executive did not satisfy the requirements for their participation. The Congress was attended by 8 German groups, 5 Jewish, 4 Russian, 3 Hungarian, as well as the Catalan, the Swedes, the Bulgarians, the Slovenians, the Czechs and the Croats. The Congress presidium rejected the request of the Frizian minority for their entry into the organization (Konhres natsionalnykh menshostei v Zhenevi, 1929).

The Congress presidium included the following representatives: D. Levytskyi - from the Ukrainians (Lviv), P. Shiman - from the Baltic Germans (Riga), M. Kurchinsky - from the Russians (Revel), L. Mockin - from the Jews (Paris), Masnons - from the Catalans (Barcelona), G. Sulo - from the Hungarians (Prague).

The UNDO representatives did not share the positions of the majority of the national minorities representatives (primarily the Jews, the Russians, the Germans, the Hungarians) who emphasized their loyalty to the countries in which they live. Their maximum demand was the cultural autonomy within the existing states and borders.

The introduction of the Ukrainians to the organization at the Vth Congress met the criticism of many Ukrainian parties that considered this step a «fake move, because 
the Ukrainian problem in Poland is reduced to the level of minor problems» (Konhres natsionalnykh menshostei v Zhenevi, 1929). D. Paliyiv, the participant of the Vth Congress responded to these objections as follows: «The very fact that we, after three years, put off (postponed - authors) by joining the minorities organization indicates that we were under this review of great doubts. When, last year, the UNDO leader decided to finally join the organization, only because the arguments for the introduction was much more than against». The Ukrainian delegation did not leave any doubts about the legitimacy of their aspirations, but met protests by the Congressional Presidency on the desire «to implement the national minorities problem in other ways». «The Ukrainian delegation in the organization remained», D. Paliyiv emphasized the following: «using the congressional program to ensure that the Ukrainian issue is properly represented in the foreign public affairs» (Konhres natsionalnykh menshostei v Zhenevi, 1929).

The researcher D. Paliyiv did not the golden opportunity to express another argument in favor of the UNDO representatives participation at the Congress. After all, the Ambassador of the Non-Party Block of Cooperation with the Government (B.SSU) Y. Bohuslavskyi (from Volyn) arrived at the Vth Congress and demanded that he should have been accepted as a member of the organization, as the representative of the Ukrainians in Poland. «It is clear that such a plan was not born in my head,» D. Paliyiv emphasized, «most of Bohuslavskyi, but they were sent to Geneva by those who were interested in the fact that one of the Ukrainians spoke at the National Minority Congress on the full satisfaction of their national rights and needs in Poland» (Konhres natsionalnykh menshostei v Zhenevi, 1929). The Ukrainian delegation was against the idea of accepting Bohuslavskyi under the threat of leaving the Congress. In this situation, the Congress approved a proposal brought in by an organizing Committee, according to which, the ambassadors were elected from the non-national lists and could be admitted to a congressional constitution, if they prove their independent activity without the influence of the other national groups on them. Therefore, D. Paliyiv assured that «it is not freely possible for us to admit to this organization people, who would represent the Ukrainian issue in Poland and the Ukrainian problem as the integrity in the false light. And in order to prevent this, we must be the members in the organization» (Konhres natsionalnykh menshostei $v$ Zhenevi, 1929). D. Paliyiv drew attention to the unexpected solidarity of the Russian delegations from Poland, Estonia, Czechoslovakia, Romania, who spoke in defense of Y. Bohuslavskyi. D. Paliyiv and V. Zalozetsky (from Bukovyna) were the Ukrainian representatives at the Congress. The UNDO representatives drew attention to the fact that «no surrender improvement to the League of Peoples considering complaints won't change the situation of those nations who have fallen to be in the role of the minorities. This has been already indicated by the Ukrainian delegation at the last Congress, because of this fact the representatives from different parties put the blame on the Ukrainians, highlighting they are working against the peace. Meanwhile, the Ukrainians don't work against peace, but all those who do not have understanding for the affairs of peoples who have fallen into the minority positions» (Konhres natsionalnykh menshostei v Zhenevi, 1929). The Congressional resolutions on the establishment of the National Research Institute (Vienna or Prague) and the formation of the Minority Journalists Union were vital (Konhres natsionalnykh menshostei v Zhenevi, 1929).

The National Minorities Congress decided to form an international association of journalists of the national minorities. This decision was immediately implemented after the end of the Congress. At the beginning of September in 1929, in Geneva, the constituent assembly of the 
association took place, attended by the dozens of journalists, and whoapproved the charter of the association and held the elections. The Board of the Association was in Geneva. The Presidium of the Society included the representatives of the most numerous nationalities. Mr Bobidnyak, the former ambassador of the Italian Parliament, the Slovenian from Italy, was elected as the Chairman of the organization unanimously. The Council members were the following representatives: Baron F. Ikskil - from the Germans; D. Paliyiv - from the Ukrainians, F. Sundan - from the Czechs, I. Greenbaum - from the Jews, B. Nikolskyi from the Russians and the others. The task of the association was to protect the professional interests of journalists of the national minorities, to strengthen peace and reach consensus among the national minorities (Mizhnarodne obiednannia natsionalnykh menshostei, 1929).

Conclusions. Consequently, the National Minorities Congresses, held annually in Geneva in the second half of the 1920-ies, became a discussion platform for negotiating a wide range of the national minorities problems in the inter-war Europe with the accedence of the League of Nations, which sent its representatives to participate in their discussions. The leaders of the Congress, J. Wilfan, E. Ammende and the others, tried to narrow the discussion of the problems of only those national minorities that were scattered in the European countries and enjoyed the support of their national powers. It was they who formed the agenda of Congresses, imposing debates on the implementation of the idea of the national and the cultural autonomy in various forms in European countries. But in Europe there were national minorities who, in separate countries (in their territories), lived compactly and in some regions constituted the majority without their national powers. The latter belonged to the Ukrainians whose representatives participated in the discussions of the above-mentioned issues. The Ukrainian position at the Congresses was represented by the UNDO representatives - the most influential Ukrainian political party in the 1920-ies (in different years, D. Levytskyi, M. Cherkavskyi, O. Levchanivskyi, D. Paliyiv, O. Maritschak, etc.) and the «Peasant Union» ( P. Vasilchuk in 1926 - 1927), as well as Bukovyna and Transcarpathia representatives. In 1925 - 1927 the Ukrainian representatives were in the status of the observers, and in the subsequent years - the sufficient participants. The Ukrainian delegation at the Congresses advocated broadening the agenda Congresses, discussing the national minorities issue in the context of implementing the principle of the national self-determination, and considering the situation of certain national minorities in the individual states. The Ukrainian delegates did not consider the Ukrainians to be a national minority in Poland, and the format of the Congress was viewed as an opportunity for the Ukrainian issue propaganda on the international scene. The allies of the Ukrainians were often the representatives of the Belarusians, the Lithuanians, and the others.

Acknowledgments. The authors sincere gratitude to all members of the editorial board for consultations provided during the preparation of the article for printing.

Funding. The authors received no financial support for the research, authorship, and/or publication of this article.

\section{BIBLIOGRAPHY}

Ammende, E. (1927). Gefährdung des europäischen Friedens durch die nationale Unduldsamkeit [Endangering European peace through national intolerance]. Wien: Jasper, 186 s. [in German].

Batóg, M. (2017). Sytuacja wyznaniowa i narodowa w II Rzeczpospolitej [Religious and national situation in the Second Polish Republic]. Rocznik Kolbuszowski, 17, 197-208. [in Polish].

Bober, S. (2018). Mniejszości narodowe w Polsce w dwudziestoleciu międzywojennym: zarys problematyki [National minorities in Poland in the interwar period: an outline of the problems]. O niepodległości ekumenicznie: wyznawcy różnych Kościołów dla Rzeczypospolitej (1918 - 1939) 
(pp. 137-145). Lublin: Towarzystwo Naukowe Katolickiego Uniwersytetu Lubelskiego Jana Pawła II. [in Polish].

Dawidowicz, A. (2016). Ludność kresowa w myśli politycznej Stronnictwa Narodowego (do 1939 roku) [Borderland population in the political thought of the National Party (until 1939)]. Polska i jej wschodni sasiedzi / red. nauk. B.Grott, O.Grott. (pp. 85-100) Warszawa : Wydawnicwo von borowiecky. [in Polish].

Do zizdu ponevolenykh v Zhenevi. (1925). Do zizdu ponevolenykh v Zhenevi [To the congress of enslaved people in Geneva]. Dilo, 24 zhovtnia. [in Ukrainian].

Figura, M. (2016). Swój czy obcy?: obraz Ukraińców w prasie wielkopolskiej, pomorskiej i śląskiej u progu II Rzeczypospolitej [Yours or strangers?: the image of Ukrainians in the Wielkopolska, Pomeranian and Silesian press at the beginning of the Second Polish Republic]. Kultury obcości / red. nauk. M.Jedliński, K.Witczak. (pp. 131-140). Bydgoszcz: Oficyna Wydawnicza Epigram. [in Polish].

Interviu. (1928). Konhres natsionalnykh menshostei i ponevoleni narody. Interviu lvivskoho zhydivskoho zhurnalista z d-rom Dm. Levytskym i bilorusom Yeremichem [The Congress of national minorities and enslaved peoples. Interview of a Lviv Jewish journalist with Dr. Dm. Levytsky and Belarusian Jeremic]. Dilo, 8 veresnia. [in Ukrainian].

Klunnyi, P. (1924). Natsionalni bilshosty ta menshosty derzhav Yevropy [National Majority and Minority in the States of Europe]. Praha, 46 p. [in Ukrainian].

Konhres menshostei. (1926). Konhres menshostei [The Congress of Minorities]. Dilo, 31 serpnia. [in Ukrainian].

Konhres natsionalnykh menshostei $\mathbf{v}$ Zhenevi. (1929). Konhres natsionalnykh menshostei $\mathbf{v}$ Zhenevi [The Congress of National Minorities in Geneva]. Dilo, 28 serpnia. [in Ukrainian].

Konhres natsionalnykh menshostei. (1926 a). Konhres natsionalnykh menshostei [The Congress of National Minorities]. Dilo, 27 serpnia. [in Ukrainian].

Konhres natsionalnykh menshostei. (1926 b). Konhres natsionalnykh menshostei [Congress of National Minorities]. Dilo, 28 serpnia. [in Ukrainian].

Konhres ponevolenykh narodiv v Zhenevi. (1927). Konhres ponevolenykh narodiv v Zhenevi [The Congress of Enslaved Peoples in Geneva]. Dilo, 21 serpnia. [in Ukrainian].

Konhres yevropeiskykh natsionalnykh menshostei. (1925). Konhres yevropeiskykh natsionalnykh menshostei [The Congress of European National Minorities]. Dilo, 21 zhovtnia.

Konhresy ponevolenykh. (1925). Konhresy ponevolenykh [The Congresses of the enslaved]. Dilo, 11 zhovtnia. [in Ukrainian].

Koziński, M. (2016). Mniejszość ukraińska w Polsce [Ukrainian minority in Poland]. Mniejszości narodowe: perspektywa sekuritologiczna / red. nauk. A. Urbanek. (pp. 108-142) Kraków: Wydawnictwo Wyższej Szkoły Bezpieczeństwa Publicznego i indywidualnego «Apeiron».

Kuhutiak, M. (2000). Ukrainske natsionalno-demokratychne obiednannia: aktyvizatsiia diialnosti, posylennia hromadsko-politychnykh vplyviv (1928 - 1930) [Ukrainian national-democratic association: activization of activity, strengthening of socio-political influences (1928-1930)]. Halychyna. Naukovyi i kulturno-prosvitnii kraieznavchyi chasopys, 4, 90-96. [in Ukrainian].

Kuhutiak, M. (2002). Istoriia ukrainskoi natsional-demokratii (1918-1929) [History of Ukrainian National Democracy (1918 - 1929)]. Vol. 1. Ivano-Frankivsk: Plai, 536 p. [in Ukrainian].

Kundera, W. (2016). Mniejszości narodowe w Polsce: zarys historyczno-prawny [National minorities in Poland: a historical and legal outline]. Studia Prawa Publicznego, 4, 109-142. [in Polish].

Levytskyi, K. (1923). Prava natsionalnykh menshostei [Rights of national minorities]. Viden, 1923. 15 p. [in Ukrainian].

Lozynskyi, M. (1923). Borotba za natsionalnyi kharakter terytorii v Versalskim dohovori [The fight for the national character of the territory in the Treaty of Versailles]. Naukovyi zbirnyk Ukrainskoho Vilnoho Universytetu, Praha, Vol. 1, 96-104. [in Ukrainian].

Mandryka, M. (1926). Natsionalni menshosti v mizhnarodnomu pravi [National Minorities in International Law]. Praha, 44 p. [in Ukrainian].

Maritchak, O. (1927). Konhres natsionalnostei v Zhenevi (vid 2 - 24 serpnia 1927) [The Congress of Nationalities in Geneva (August 2 -24, 1927)]. Dilo, 4 veresnia. [in Ukrainian]. 
Maritchak, O. (1928). Zizd ponevolenykh natsionalnostei u Zhenevi [The Congress of enslaving nationalities in Geneva]. Dilo, 1 veresnia. [in Ukrainian].

Marszal, M. (2014). Polska myśl konserwatywna wobec «kwestii ukraińskiej» w okresie międzywojennym [Polish conservative thought towards the «Ukrainian question» in the interwar period]. Studia Prawno-Ekonomiczne, 91 (1), 87-101. [in Polish].

Menshostevyi olimp. (1927). Menshostevyi olimp [Olympus of Minorities]. Dilo, 3 veresnia. [in Ukrainian].

Mizhnarodne obiednannia natsionalnykh menshostei. (1929). Mizhnarodne obiednannia natsionalnykh menshostei [The International Association of National Minorities]. Dilo, 13 veresnia. [in Ukrainian].

Novynky. (1926). Novynky. Ukrainska delehatsiia na konhresi natsionalnykh hrup [Novelty. Ukrainian delegation at the congress of national groups]. Dilo, 25 serpnia. [in Ukrainian].

O. N. (1926). Na Zhenevskii areni. Konhres menshostei i nepolski narody z-pid Polshchi [On the Geneva arena. The Congress of Minorities and Non-Permanent Peoples from under the Poland]. Dilo, 1 veresnia. [in Ukrainian].

Pislia konhresu menshostei. (1926). Pislia konhresu menshostei. Z holosiv presy [After the Congress of minorities. From the voices of the press]. Dilo, 9 veresnia. [in Ukrainian].

Pislia konhresu. (1926). Pislia konhresu [After the Congress]. Dilo, 7 veresnia. [in Ukrainian].

Pisuliński, J. (2017). Ukraińskie skargi w Lidze Narodów na nieprzestrzeganie przez Polskę traktatu mniejszościowego [Ukrainian complaints in the League of Nations on non-compliance by Poland with a minority treaty]. Politycy, dyplomaci $i$ żolnierze: studia i szkice z dziejów stosunków międzynarodowych w XX i XXI wieku ofiarowane Profesorowi Andrzejowi Maciejowi Brzezińskiemu w 70. rocznice urodzin / pod red. D. Jeziornego, S. M. Nowinowskiego, R. P. Żurawskiego. (pp. 147-158). Łódź : Wydawnictwo Uniwersytetu Łódzkiego. [in Polish].

Rudnytska, M. (1998). Statti, lysty, dokumenty [Articles, letters, documents]. Lviv-Zhovkva: Misioner, 844 s. [in Ukrainian].

Tomczyk, R. (2006). Ukrainskie Zjednoczenie Narodowo-Demokratyczne 1925 - 1939 [Ukrainian National-Democratic Union 1925 - 1939]. Szczecin: Ksiaznica Pomorska, 294 s. [in Polish].

Torzecki, R. (1989). Kwestia ukraińska w Polsce w latach 1923 - 1929 [The Ukrainian problem in Poland in 1923 - 1929]. Kraków: Wydawnictwo Literackie, 468 s. [in Polish].

Vasiuta, I. (2006). Politychna istoriia Zakhidnoi Ukrainy (1918 - 1939) [Political History of Western Ukraine (1918 - 1939)]. Lviv: Kameniar, 335 p. [in Ukrainian].

Zaitsev, O. (1993). Predstavnyky ukrainskykh politychnykh partii Zakhidnoi Ukrainy v parlamenti Polshchi (1922 - 1939 rr. ) [The representatives of Ukrainian Political Parties of Western Ukraine in the Parliament of Poland (1922 - 1939)]. Ukrainskyi istorychnyi zhurnal, 1, 72-84. [in Ukrainian].

Zaitsev, O. (1994). Natsionalizm i natsionalna demokratiia: vytoky konfliktu (1920 - 1930-i rr.) [Nationalism and national democracy: the origins of the conflict (1920s - 1930s)]. Suchasnist, 2, 7076. [in Ukrainian].

Zhenevska konferentsiia. (1925). Zhenevska konferentsiia [Geneva Conference]. Dilo, 14 zhovtnia. [in Ukrainian].

The article was received on April 3, 2019. Article recommended for publishing 10/06/2019. 